\title{
Fatherless in indonesia and its impact on children's psychological development
}

\author{
Yulinda Ashari ${ }^{1}$ \\ 1. Faculty of Psychology UIN Syarif Hidayatullah Jakarta \\ *E-mail: yulindaashari.psi@gmail.com
}

\begin{abstract}
The power of the child's personality is the result of good parenting and handling by both of parents. If one is absent, there will be an imbalance to child psychological development. The fatherless concept itself can be interpreted as the absence of a father figure in the nurturing process. Then known the "fatherless", "father absence", "father loss" or "father hunger". The fatherless issue has become an international problem, including in Indonesia. Most cases in Western countries are the absence of fathers due to unmarried fathers and mothers, it's different with Indonesia's problems, the fathers and mothers are married, but the execution of the parenting tasks is neglected or unfulfilled. Many children have a physical father but at the same time fatherless psychologically. It seems the traditional parenting pattern in Indonesia that the role of mother is taking care of the child at home and father is working to earn a living is still believed without further meaning. Father contributes importantly to the development of the child, the experience with father will affect a child to adulthood later. Father has influences in some special areas of child development, which teaches freedom, expands children's view, firm discipline, and role models of male. It is hypothesized that fatherless will give negative impact to psychological development of children. The literature reviews is used to support the hypothesized in this paper.
\end{abstract}

\section{Keywords: Children; Children's psychological development; Fatherless; Indonesia; Parenting}

\section{Introduction}

Educating a child is the job of both parents, father and mother, not one of them. The character of a strong childhood personality is the result of a balanced parenting of both parents. Each father and mother have an important role for each other in the nurturing process. If one role is not present in a family, then the parenting process is not perfect. This can then lead to imbalances in the child's psychological development. The issue of the absence of the father's role has attracted quite a few researchers in the past few years. The loss of father's role or then called fatherless began to become a concern in the international world. The phenomenon of fatherless in Indonesia itself is not a new thing. It is interesting to discuss when Western countries experience fatherless as unmarried father and mother, whereas in Indonesia most couples are legally married, but the role of fathering is still neglected. It seems like the traditional parenting patterns that the mother at home take care of the child and father work to earn a living still believed without further meaning. Throughout the history, in some societies of the world, a man is responsible for feeding his wife and children, while a woman is more likely to keep a house, prepare food regularly and raise her children (Duvall, 1977). In fact, the father's duty in the family is not just to make a living in the form of material, but also need to contribute in providing affection and role model for their children. In some cases, children experience fatherless because their fathers have passed away, but then many children who have father physically but at the same time fatherless psychologically. Some campaigns such as "Indonesia Darurat Ayah" 
to Indonesian nickname as "Fatherless Country" called for fathers to return and can be involved in this child parenting process (poskotanews.com \& liputan6.com).

Personality, mental health and coping stress will be difficult to do by children who do not get parenting from the father and mother. (Sundari \& Herdajani, without years). Indonesian children have a physical father, but many of them do not have a psychological father. As if the duty of the father is only work and the mother's duty is to nurture. In fact, the process of parenting should be done together, the father and mother have their important roles in the process of parenting. Fatherless phenomenon in Indonesia became interesting related inequality of father role in child care process. The term of fatherless is understood as the absence of father's role and figure in a child's life. It happens to orphans or children who are not close to their father physically or psychologically.

This paper is expected to awaken the father to return to play a role in the care of children in the family. It is important for parents and prospective parents to understand the role of the father in care of the child's psychological development until they become an adult. Traditional assumptions and prestige of the father to be involved in parenting must be eliminated given the importance of the father's role that can not be replaced by other figures. This paper discusses more about fatherless in Indonesia and its impact on children's psychological development. The author hopes that the future father can divide the role in working to earn a living and take the time to interact in quantity and quality with his children at home. The hypothesis is built in the form of negative impact of the absence of the father role in the process of parenting to the psychological development of children, such as affection, emotion, and behavior.

\section{Methods}

The research method of this paper is literature review through journals, scientific articles, and research related to the problem of absence of father role in parenting or fatherless. The keywords that used in the search of scientific literature are fatherless, fathering, fatherhood, parenting, father role, child development, and child's psychological development. The literature review attempts to synthesize the theories with phenomena that is occurring at the real life. Both qualitative and quantitative data are presented to support the initial hypothesis.This section usually consists of the description of research participants, including the number, characteristics, sampling method, and recruitment process, if necessary.

\section{The concept of Fathering and Fatherless Research}

The role of father or fathering refers more to his role in parenting. This is because fathering is the part of parenting. Ideally fathers and mothers take the complementary roles in their domestic and marriage life, including acting as a complete role models for children in living their lives (Andayani \& Koentjoro, 2004). Father and mother have their respective roles in the parenting process and cannot be replaced by other figures. Loss of one parent role, both fathering and mothering, will cause inequality to the child psychological.

The fatherless concept itself can be interpreted as the absence of a father figure in the nurturing process. Then known the "fatherless", "father absence", "father loss" or "father hunger". The absence of the father's role physically due to death leads to the orphan's name. But if his absence is due to there is no father role while there is a father his, then the child can be said to be orphaned before the time. They have father, but fatherless.

In the other literature, the fatherless is the absence of the role and father figure in a child's life. This happens to orphans or children who in their daily lives do not have a close relationship with their father. As stated by Smith (2011) that a person is said to have a fatherless condition when he has no father or no relationship with his father, due to divorce or parental marriage issues. According to the website www.cyep.org writes that the fatherless issue has become an international problem. Fatherless occurs in America, Sweden, England, Canada, Australia, Norway, Cuba, Trinidad and Tobago, Cameroon, Africa, the Netherlands and Finland. Most cases in Western countries are the absence of fathers due to unmarried fathers and mothers, while in Indonesia's problems, the fathers 
and mothers are married, but the execution of parenting tasks is neglected or unfulfilled.

Lamb, et al (in Palkovits, 2002) divides paternal involvement of father in 3 components:

1. Paternal engagement: parenting involving direct interaction between father and child, for example through playing, teaching something, or other leisure activities.

2. Accessibility or availability interacts with the child when needed. This is more temporal. Father and child have interaction just in case the child have a bussiness with his or her father.

3. Responsibilities and roles in terms of developing child care plans. In this component father is not involved in nurturing (interaction) with her child. It is believed that the role of father is just to work and earn money, while the parenting process is a mother's role.

Palkovits (2002) concludes that father involvement in parenting has several definitions, including:

1. Engage with all activities performed by the child (McBride \& Mills, 1993),

2. Make contact with the child,

3. Financial support, and;

4. The amount of play activities done together.

Involvement in parenting is also defined as how much effort a father does in thinking, planning, feeling, watching, monitoring, evaluating, worrying and praying for his child (Palkovits, 2002). Judging from the child's perspective, father involvement is associated with the availability of opportunities for the child to do something, care, support and security. Children whose fathers are involved in nurturing themselves will have good social and cognitive skills, as well as high self-esteem (Palkovits, 2002). This happens when the father develops a positive parenting model. Involvement will have a negative effect if in the practice of parenting, the father exhibits negative behavior, and involves corporal punishment. From the above it can be concluded that the involvement of the father in parenting will bring great benefits to the child's development, only when the involvement is appropriate, warm, positive, building and facilitating the child to develop.

\section{Results}

According to Cabrera et al (2000), father contributes importantly to the development of the child, the experience shared with the father, will affect a child to adulthood later. The role of parenting behaviors affects the development and welfare of children and the transition to adolescence. Of course this is not something that can be underestimated, because the role of father is very important and have an impact on the psychological development of children and adolescents.

Lerner (2011) states, the absence of father's important roles will have an impact on the low selfesteem when he matures, anger, shame because it is different from other children and cannot have experience of being together with a father that felt by other children. The loss of the father's role also causes a child to feel loneliness, envy, and grief, (Lerner, 2011) and the great loss, accompanied by low self-control (Kruk, 2012), low initiative risktaking (Williams, 2011), and low psychological well being (Bronte-Tinkew, Horowitz, and Scott, 2009). They also have the tendency to have neurotics, especially in girls (Thomas, 2009). The psychological consequences felt by the child have an impact on the deviation of behavior and the meaninglessness of his life. So, the role of father is very important and need to get more attention in the process of parenting and child development.

A longitudinal study on grade 4 students of Elementary School found a higher level of aggression in boys who only lived with mothers, (Vaden-Kierman et al. 1995; Osborne and McLanahan, 2007). This study indicates that boys who do not get a parenting role from their fathers tend to grow up to be children who are vulnerable to juvenile delinquency, low commitment and emotional control, and high levels of aggressiveness.

In another study of family vulnerability and a wellbeing survey or well-being in children, it was found that a father who has children with more than one 
partner will affect the child's health as a teenager, and negative behavior both directly and indirectly (Bronte- Tinkew, Horowitz and Scott, 2009). This is related to the commitment of the father to be faithful to the couple and fair in giving attention and affection. Furthermore, problems with health in children, physically and mentally, are also found in boys living with single or maternal parents only (Hong and White-Means, 1993). It cannot be denied that the role of father and mother in the nurturing process can have a lot of impact on the physical and psychological children.

Another research studies conducted by Kandel et al (1994), found fatherless effects in children, which have problems with anxiety and depression disorders, to become psychiatric patients in the hospital, involved with early sexual activity, drug abuse, mood disorders, And involved serious or criminal mischief. A further longitudinal study by Koestner, Franz \& Weinberger (in Santrock, 2007) mentions that father involvement in child rearing at age 5 is the strongest determinant of empathy for men and women aged 31 years. In further studies, at the age of 41 years, men and women who have better social relationships namely the quality of marriage and friendship, have experienced more father warmth in childhood. The author state some other impacts of fatherless include:

- Boys that are close with their fathers have better attitudes about intimacy and the prospect of their own people who do not feel close to their fathers.

- The child with an available father is more companionable and responsible as an adult.

- Boys and girls who live gratification, have poor impulse control over anger and sexual gratification, and have a weaker sense of right and wrong.

- Children who live without their fathers are, on average, more likely to choose deviant peers, be at higher risk for peer problems, and be more aggressive. (Hetherington \& Stanley-Hagan, 1997; Horn \& Sylvester, 2002; Kelly, 2000; Painter \& Levine, 2000) .

- In father absent homes, boys, on average, are more likely to be more unhappy, sad, depressed, dependent, and hyperactive. Girls who grow up in father absent homes are more likely to be overly dependent (Mott et al., 1997) and have internalizing problems such as anxiety and depression (Kandel, Rosenbaum, \& Chen, 1994).

- Children who live without their fathers are, on average, more likely to choose deviant peers, have trouble getting along with other children, be at higher risk for peer problems (Mott et al., 1997), and be more aggressive (Horn \& Sylvester, 2002).

- Children who live without their fathers are, on average, are at greater risk of being physically abused, of being harmed by physical neglect, or of suffering from emotional neglect (Sedlak \& Broadhurst, 1996). Discussion \& Conclusion

\section{Discussion.}

In addition to the Western countries as previously mentioned, the phenomenon of the fatherless state also occurs in Indonesia, whether perceived or not. A child is unable to fully realize that he is experiencing a fatherless condition until he feels the impact of the condition in him. This can happen because this condition is not obtained instantaneously, but slowly. It really depends on individual differences, which means depending on the sensitivity of each person, and how much he is willing to find out the emptiness. The void of a father's figure felt by a child is not immediately instantaneous. Feelings of loss (feeling lost) was originally a question of the existence of a father in the mind of a child. If he does not get an answer that satisfies his longing or loss, he will keep it in his heart and continue his quest. The child begins to ask his closest people about father, or even closer to a male figure outside his father.

A kinship culture in lumpy Indonesia becomes its own luck with its "not being felt" fatherless, but it also can not be tolerated and will deteriorate if left alone. Families who are not intact because of the absence of a father figure, more covered from the child by replacing his position by the mother. This is often not felt by the families in Indonesia, so he feels that his family is fine. Father who goes to work in the morning while the child is still asleep and returns home at night when the child is asleep. Time with the child becomes very limited. 
According to Grimm-Wassil (in Thomas, 2008) fathers have influence in some special areas of child development:

A. Father teaches / encourages freedom, in general the father tends to be less protective, encourages exploration and risk taking, and he is a model of aggressive or assertive behavior.

B. Father expands the view of the child, the father introduces the outside world through their jobs.

C. Dad is a firm disciplinarian, giving little permissiveness and tends to demand a lot from their children for each stage.

\section{Father is a male (model).}

The role of father and mother cannot be replaced by other figures such as grandparents, let alone substitute figures such as baby sitter. The traditional parenting thinking that nurturing is only the task of the mother must be straightened out. Children learn the softness of the mother, and learn the firmness of a father. This is a major support in the physical and psychological development of children. In addition, well-balanced parenting and compassionate love from fathers and mothers to children can improve family resilience and harmonization.

\section{Conclusions.}

Based on the literature review that has been done, the absence of father role in parenting has a negative impact on the psychological development of children. Parents need to be aware that parenting is not just a mother's job or one of the two, but must work together and integrate with each other. The traditional thinking and prestige of fathers to engage in parenting should be eliminated to help the child grow optimally. The role of the father is not only limited to making a living, but also a role model for children to learn about the firmness and strong to reject all the negative things offered by the outside world or child's peers. Indeed, the role of the father in the parenting involvement is divided into two, the first is related to how much time is spent with the child, and the second is related to the quality of the relationship built between father and child.The quantity time that spent by father and child is important, but to have a quality time father and child interaction is more important. There are needs to be a balanced proportion between the quantity and the quality of time spent by fathers and children in a parenting process. With the involvement of the father in the process of care, children are expected to grow and develop properly and optimally in accordance with what should happen.

\section{Sugestion}

This finding is expected to awaken the father to return to his role as a parent. It can also be a consideration for incorporating the role of the father when it is discovered that delinquency occurs in adolescents or children. This paper still has many limitations. Research on fatherless data in indonesia is still limit and not clear. The literature used mainly refers to research in the western countries which may differ from its influence on the Eastern Countries. Qualitative and qualitative research directly to children is needed to increace the literatures on fatherless in Indonesia.

\section{References}

Abdullah, M.S. (2010). Studi eksplorasi tentang peran ayah dalam pengasuhan anak usia dini. Jurnal Spirits, Vol. 1 No. 1.

Allen, S., Daly, K. (2007). The Effects of Father Involvement: An Updated Research Summary of the Evidence.Father Involvement Research Alliance, 9.

Andayani, B. \&Koentjoro. (2004). Peran Ayah Menuju Coparenting. Sepanjang : CV. Citra Media.

Block, Jack et al. (1988). Parental functioning and the home environment infamilies of divorce.Journal of the American Academy of Child and Adolescent Psychiatry, Vol. 27.

Bronte-Tinkew, J., Horowitz, A., \& Scott, M. E. (2009). Fathering with multiple partners: links to children"es well-being in early childhood. Journal of Marriage and Family, Volume 71,: 608-631.

Cabrera, N., Tamis-Lemonda, C., Bradley, R., Hofferth, S. \& Lamb, M. (2000). Fatherhood in the $21^{\text {st }}$ Century. Journal of Child Development, 71, 127-136.

Duvall, E.M. (1977). Marriage and family development.

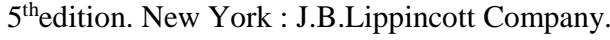

Erawati, M. (2009). Kajian metaanalisis keterlibatan ayah dalam pengasuhan dan externalizing behavior pada anak. Indigenous, Jurnal Ilmiah Berkala Psikologi. Vol. 11 No. 1, 2-19

Fergusson, D. M., Horwood, J., \& Lynsky, M. T. (1944). Parental separation, adolescent psychopathology, and problem behaviors. Journal of the American Academy of Child and Adolescent Psychiatry, Vol. 33. 
Hetherington, E. M., \& Stanley-Hagan, M. M. (1997). The effects of divorce on fathers and their children. In M. E. Lamb (Ed.), The role of the father in child development (3rd ed., pp.191-211). New York: John Wiley \& Sons, Inc.

Hidayati, F., Kaloeti, D. V. S., \& Karyono. (tanpa tahun). Peran ayah dalam pengasuhan anak. Fakultas Psikologi Universitas Diponegoro

Horn, W. F., \& Sylvester, T. (2002). Father Facts (4th ed.). National Fatherhood Initiative. [On-line]. Available: http://www.fatherhood.org/fatherfacts.htm

Kelly, J. B. (2000). Children's adjustment in conflicted marriage and divorce: A decade review of research. Journal of the American Academy of child and Adolescent Psychiatry, 39, 963 - 973.

Kandel, D. B. (1990). Parenting styles, drug use, and children's adjustment in families of young adults. Journal of Marriage and the Family, 52, 183-196.

Mott, F. L., Kowaleski-Jones, L., \& Mehaghan, E. G. (1997). Paternal absence and child behaviors: Does gender make a difference? Journal of Marriage and the Family, 59 (1), 103-118.

Painter, G., \& Levine, D. I. (2000). Family structure and youths' outcomes: Which correlations are causal? Journal of Human Resources, 35(3), 524-549

Palkovitz, R. (2002). Involved fathering and child development: Advancing our understanding of good fathering. In C. S. Tamis-LeMonda \& N. Cabrera (Eds.), Handbook of father involvement: Multidisicplinary perspectives (pp. 119 - 140). Mahwah, New Jersey: Lawrence Erlbaum Associates.
Risch, S. C., Jodl, K. M., \&Eccles, J. S., (2004). Role of the Father-Adolescent Relationship in Shaping Adolescents' Attitudes Toward Divorce.Journal of Marriage and the Family.66: 55.

Santrock, J.W. (2007). Child development. 11th edition. New York : McGraw-Hill Companies, Inc.

Sedlak, A. J., \& Broadhurst, D. D. (1996). The third national incidence study of child abuse and neglect: Final report. US Department of Health and Human Services. National Center on Child Abuse and Neglect. Washington DC, September.

Snarey, J. (1993). How Fathers Care for the Next Generation. Cambridge, MA: Harvard University Press

Sundari, A. R., \& Herdajani, F. (tanpa tahun). Dampak fatherless terhadap perkembangan Psikologis anak. Fakultas Psikologi Universitas Persada YAI

Vaden-Kierman, N., Ialongo, N., Pearson, J., \&Kellam, S. (1995). Household family structure Andchildren's aggressive behavior: a longitudinal study of urban elementary schoolchildren. Journal of Abnormal Child Psychology, Volume 23, No. 5.

Wahyuningrum, E. (tanpa tahun). Peran ayah (fathering) pada pengasuhan anak usia dini: sebuah kajian teoritis. Fakultas Psikologi Universitas Kristen Satya Wacana. 